Brasil os SC venham se articulando com a sociedade civil, ou com o poder público, para se converterem em espaços orientados nâo só para a consumo, mas também para uma plenta sociabilidade e para a cultura" (p.29).

Trata-se, no fundo, de uma problemática que em nosso país passa pela discussão de um sentido de modernidade onde as esferas do consumo e da cidadania estejam relacionadas.

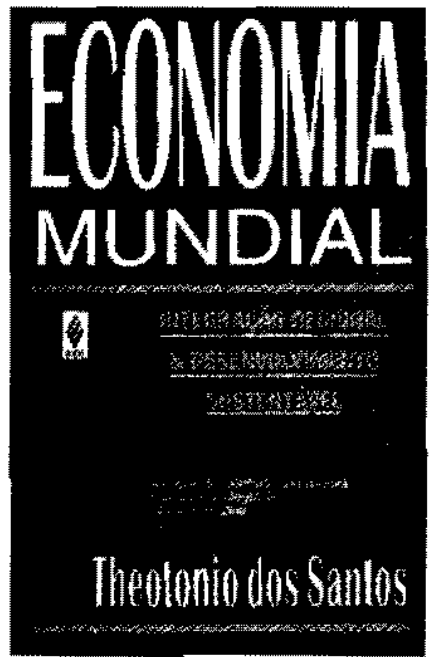

\section{ECONOMIA MUNDIAL - INTEGRAÇÃO REGIONAL \& DESENVOLVIMENTO SUSTENTÁVEL}

\section{de THEOTONIO DOS SANTOS}

Rio de Janeiro: Vozes, 1993, $144 \mathrm{p}$.

por José Carlos Barbieri, Professor Assistente do Departamento de Administração da Produção, Logistica e Operações Industriais da EAESP/FGV.

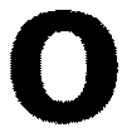

livro do professor Theotonio dos Santos analisa as mudanças que estăo ocorrendo na economia mundial e faz uma ampla reflexão. sobre a posição da América Latina e Caribe neste novo contexto. Sua análise tem como referência temporal a década de 80 , quando se consubstancia a emergência de um novo sistema econômico mundial, caracterizado por intensos processos de globalização e de regionalização, sendo esta última expressão intermediária daquela. Para o autor, esses processos e todas as crises que se observam na atualidade prenunciam o surgimento de uma nova civilização planetária, onde não haverá mais espaços para as pretensões de hegemonias de quem quer que seja. $\mathrm{O}$ autor adverte para o fato de a humanidade encontrar-se frente a grandes desafios, que exigem profundas reflexões sobre o sistema de gestão da economia mundial, bem como de soluções globais, produtos de negociaçōes globais.

Esta obra se contrapõe às teses neoliberais e ao tom triunfalista que os seus defensores passaram a exibir após o desmantelamento da ex-URSS e da rendição da China e de outros países socialistas aos ditames da economia de mercado. As soluçōes globais de que fala Theotonio dos Santos devem ser pautadas pelos princípios do planejamento autoconsciente e não pelas idéias de ajustes automáticos via mercado e tampouco pela lei das vantagens comparativas presidindo as relaçôes comerciais entre países e regiōes. $O$ tex to também faz uma critica a esse triunfalismo que tomou impulso com o fim da Guerra Fria e a crise do socialismo real, à medida que expõe a outra face da prosperidade obtida no mundo capitalista, com as centenas de conflitos armados, desemprego crescente, violência, criminalidade e outras mazelas que também estão presentes dentro das próprias regióes desenvolvidas.

Questões como essas são debatidas ao longo dos treze capítulos que compöem o livro em tela e que foram escritos a partir de uma pesquisa que o autor vem realizando com apoio de diversas agências nacionais e internacionais, tais como o CNPq, a Fundação Ford e a Universidade das Nações Unidas. Embora rico em informações, principalmente sobre conferências intergovernamentais e sobre a atuação de organismos internacionais (ONU - Organização das Naçōes Unidas, PNUMA - Programa das Nações Unidas para o Meio Ambiente, FMI - Fundo Monetário Internacional, UNCTAD - Conferência das Naçóes Unidas para o Comércio e o Desenvolvimento, GATT - Acordo Geral de Conexäo e Tarifas, Banco Mundial etc.), o livro não se parece nada com um típico relatório de pesquisa, cheio de citações, tabelas e gráficos. Longe disso, o texto apresenta-se como um manifesto, onde o autor faz uma defesa vigorosa sobre a necessidade de se construir uma nova ordem internacional baseada nos principios do desenvolvimento sustentável. Princípios estes que têm como ponto central a erradicação da pobreza e de qualquer forma de opressão. Dentro das idéias que orientam a busca desse tipo de desenvolvimento, não cabem segmentos excluídos $\mathrm{e}$, no plano internacional, relações de dominação. 
Um aspecto fundamental desse livro refere-se à análise que o autor faz da Revoluçẫo Científico-Técnjca (RCT), um tema recorrente desse autor e que ele o explora com mais profundidade em outras obras, principalmente em Revoluço Cientifífo-Técnica e Capitalismo Contemporâneo, de 1983, também editado pela Vozes. É em tomo das interaçoes entre a RCT e o processo de globalização da economia que o autor constról a sua argumentaçăo básica para analisar a posição da América Latina e Caribe diante das mudanças que estẫo ocorrendo no cenário internacional, bem como para propor caminhos alternativos para esta região, caminhos que passarão necessariamente por uma integração regional capaz de romper com o modo dependente e subalterno que tem caracterizado a sua inserção na economía mundial. Através da análise de projetos de integração, fracassados ou em curso, a exemplo da ALALC - Associação Latino-Americana de Livre Comércio e do Pacto Andino, o autor discute os limites e as dificuldades para se alcançar esse tipo de integração regional. Os últimos capítulos são dedicados a este assunto e constituem uma importante contribuiçăo para o debate que atualmente se faz em torno do MERCOSUL e do NAFTA - Acordo de Livre Comércio da América do Norte.

Mesmo sem fazer concessöes aos problemas que afetam a América Latina e o Caribe, o texto traz uma mensagem otimista, pois a crise de hegemonia no mundo contemporâneo, um aspecto importante da conjuntura internacional, favorece a negociaçăo $\mathrm{e}_{\text {, }}$ assim, essa regiâo passa a ter "uma oportuntdade unica para afirmar a sua unidade sem chocar-se abertamente com a hegemonia americana" (p. 139). Concluindo, trata-se de uma obra importante e que estava faltando, não só porque estabelece um confronto com as teses neoliberais muito em voga no momento, mas principalmente porque continua o debate sobre o desenvolvimento sustentável, que teve na Eco-92, em julho de 1992, no Rio de Janeiro, um form de discussões privilegiadas.

\section{THE JAPANESE POWER GAME: WHAT IT MEANS FOR AMERICA}

de WILLIAM J. HOLSTEIN

New York: Penguin Books, 1991, 351 p.

por Gilmar Masiero, Doutorando em Administração na EAESP/FGV.
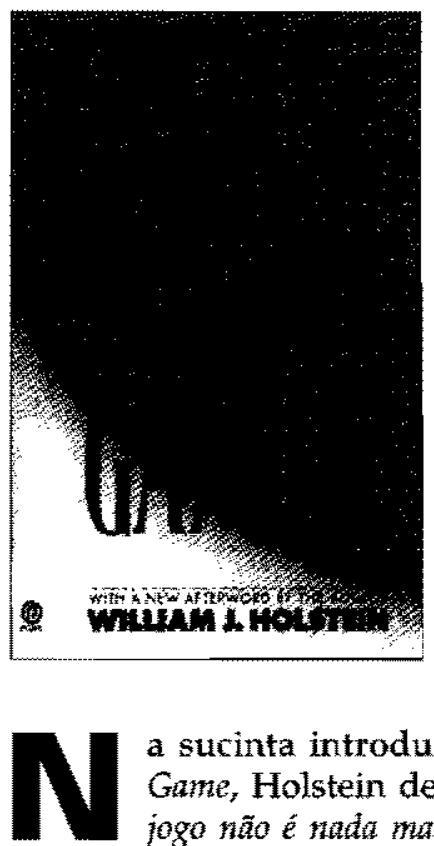

a sucinta introduçấo ao The Japanese Power Game, Holstein declara que ".. o que esta em jogo não é nada mais nada menos que a modelagem do século XXI. Agora que os japoneses passaram os soviéticos, Estados Unidos e Japão são as duas maiores ecorommias mundiais. Em toda a história, paramente duas socie dades com tâo diferenciados valores têm se permitido tornarem-se tão interdependentes. Embora as duas possuam áreas de genutna cooperação, elas estão também engajadas em sérias confrontaçöes. E mais que una disputa econômica. É uma questao de quais regras e quais valores iräo prevalecer. Então, como o jogo do poder é jogado internamente e como o Japão joga internacionalmente são importantes questões".

Essas questões são respondidas em 351 păginas do melhor jornalismo mundial, organizadas em um livro composto de 23 subtítulos distribuídos em quatro partes: A sociedade poderosa; Escândalo; Na direção do futuro; Resposta americana. No final do livro, encontram-se dois apêndices com resultados de pesquisas sobre o que os japoneses pensam dos Estados Unidos e o que os americanos pensam da Empresa Japonesa. Na edição de 1991, um novo posfácio é publicado.

A visão americana média e de praticamente todo o Ocidente sobre o Japão do imediato pós-guerra até nossos dias é que o imperador japonês e sua força armada, numa desenfreada ambição de poder, expandiram sua área de ação nos anos 20 e 30 cometendo todo tipo de atrocidades, especialmente contra o povo coreano e chinês. Esta política expansionista culminou com o ataque à base naval americana Pearl Harbor, que foi de imediato respondido pelos Estados Unidos. Com o lançamento das bombas atômicas sobre Hiroshima e Nagazaki em 1945, o Japão deu-se por vencido e as Forças de Ocupação permaneceram naquele território até 1952. Os Estados Unidos ajudaram a reconstruir a sociedade e a economia japonesas através de vários mecanismos como a transferéncia tecnológi- 